УДК 378.147:53

DOI https://doi.org/10.26661/2522-4360-2021-2-08

\title{
3D-РУЧКА ЯК ЗАСІБ ФОРМУВАННЯ ОТЕМ-КОМПЕТЕНТНОСТІ УЧНІВ ОСНОВНОЇ ШКОЛИ ПІД ЧАС НАВЧАННЯ ФІЗИКИ
}

\author{
Трифонова О. М. \\ доктор педагогічних наук, доцент, \\ доиент кафедри природничих наук та методик їхнього навчання \\ Центральноукраӥнський державний педагогічний університет \\ імені Володимира Винниченка \\ вул. Шевченка, 1, Кропивницький, Украӥна \\ orcid.org/0000-0002-6146-9844 \\ olenatrifonova82@gmail.com
}

\begin{abstract}
Ключові слова: освітній прочес, навчання фізики, 3D-ручка, ичифровізаичія, STEM-компетентність, активізація пізнавальної діяльності.
\end{abstract}

Особливого значення в сучасних умовах набуває процес навчання фізики як основи для розвитку автоматизованих систем, робототехніки, мехатроніки, STEM-технологій та науково-технічного прогресу в цілому. При цьому прослідковується ряд системних проблем щодо реального стану реалізації освітньої політики в Україні із впровадження засад цифровізації в освітньому процесі. Окреслені проблеми передбачають потребу створення та забезпечення систематичного функціонування STEM-освітнього середовища, основою якого $є$ STEM-технології навчання природничо-математичних дисциплін. Як один із шляхів реалізації STEM-технологій автори запропоновали навчання засобів тримірного зображення натурних і модельних явищ, процесів, що має інноваційно-орієнтоване спрямування. Методичні особливості реалізації зазначеного підходу передбачають: 1) ознайомлення здобувачів освіти 3 основами сучасного 3D-конструювання та моделювання; 2) формування вмінь використовувати 3D-пристрої, найпростішим з яких є 3D-ручка; 3) розвиток STEM-компетентності, здатності до організації власної проектної діяльності та передбачення ㄲi результатів; 4) активізацію пізнавальної активності здобувачів освіти, розвиток їхніх інтелектуальних i творчих здібностей, акцентування уваги на перспективності професій, пов'язаних із природничо-математичною галуззю знань. Із метою забезпечення формування STEM-компетентності учнів основної школи під час навчання фізики нами визначено особливості запровадження використання 3D-ручки в освітньому процесі. Запропоновані елементи впровадження 3D-ручки як засобу навчання в освітній процес iз фізики забезпечують підвищення пізнавальної активності учнів, сприяють реалізації принципу політехнічної направленості навчання фізики. Формування таким чином STEM-компетентності вчить учнів самостійно мислити, отримувати та застосовувати знання, планувати свою діяльність, приймати рішення, презентувати результати діяльності, ефективно працювати в STEM-освітньому середовищі, сприяє розвитку в них комунікативної компетентності. 


\title{
3D-PEN AS A MEANS OF FORMING STEM-COMPETENCE OF PRIMARY SCHOOL STUDENTS IN TEACHING PHYSICS
}

\author{
Tryfonova O. M. \\ Doctor of Pedagogical Sciences, Associate Professor, \\ Associate Professor at the Department of Natural Sciences and Methods of their Training \\ Volodymyr Vynnychenko Central Ukrainian State Pedagogical University \\ Shevchenko str., 1, Kropyvnytskyi, Ukraine \\ orcid.org/0000-0002-6146-9844 \\ olenatrifonova82@gmail.com
}

Key words: educational process, teaching physics, 3D-pen, digitization, STEM-competence, activation of cognitive activity.
Of particular importance in modern conditions is the process of teaching physics. Physics is the basis for the development of automated systems, robotics, mechatronics, STEM-technologies and scientific and technological progress in general. At the same time a number of system problems are traced. They reflect the real state of implementation of educational policy in Ukraine and the introduction of the principles of digitalization in the educational process. The outlined problems include the need to create and ensure the systematic functioning of STEM-educational environment. The basis of such an environment is STEM-technology of teaching natural sciences and mathematics. The authors proposed the implementation of STEMtechnologies through the training of means of three-dimensional depiction of natural and model phenomena, processes, which has an innovation-oriented direction. Methodological features of the implementation of this approach include: 1) acquaintance of students with the basics of modern 3D-design and modeling; 2) the formation of skills to use 3D-devices, the simplest of which is a 3D-pen; 3) development of STEM-competence, ability to organize own project activity and prediction of its results; 4) activation of cognitive activity of students, development of their intellectual and creative abilities, emphasis on the prospects of professions related to the natural sciences and mathematics. In order to ensure the formation of STEM-competence of primary school students during the study of physics, we have identified the features of the introduction of the use of 3D-pen in the educational process. The proposed elements of the introduction of 3D-pen as a means of teaching in the educational process in physics provide an increase in cognitive activity of students, contribute to the implementation of the principle of polytechnic orientation of teaching physics. The formation of STEM-competence teaches students to think independently, receive and apply knowledge, plan their activities, make decisions, present results, work effectively in STEM-educational environment, promotes the development of communicative competence.
Постановка проблеми. Визначальними чинниками становлення та розвитку держави є сучасні наукоємні технології, які знаходять свою реалізацію у практиці життя людей. Нині в Україні, як і в усьому світі, спостерігається дефіцит фахівців здатних впроваджувати високотехнологічні процеси у практику життя суспільства.

Як зазначено в Концепції розвитку природничо-математичної освіти (STEM-освіти) [2], основною причиною такого дефіциту є втрата популярності науково-технічних, інженерних професій i, як наслідок, зниження рівня зацікавленості у вивченні предметів природничої, технологічної, математич- ної освітніх галузей серед здобувачів освіти, про що свідчить, зокрема, негативна динаміка кількості випускників закладів загальної середньої освіти, які проходять зовнішнє незалежне оцінювання 3 математики, фізики, хімії та біології. Тож, на нашу думку, сприяти формуванню інтересу учнів до опанування предметів природного-математичного профілю слід починати 3 перших уроків.

Особливого значення в сучасних умовах набуває процес навчання фізики як основи для розвитку автоматизованих систем, робототехніки, мехатроніки, STEM-технологій та науковотехнічного прогресу в цілому. 
Проведені нами дослідження [8] дають змогу стверджувати, що сучасні цифрові (ЦТ) та хмарні технології дають змогу описувати теоретичну складову частину функціонування техногенно-цифрового освітнього середовища (рис. 1). ЦТ виконують уже інші функції практичного спрямування, до яких належать: дослідження конкретного явища, процесу; створення технології за схемою: прилад $\rightarrow$ датчик $\rightarrow$ дослідна чи виробнича система зв'язку з комп'ютером $\rightarrow$ спостереження (монітор комп'ютера) $\rightarrow$ вимірювання та обчислення $\rightarrow$ повторення процесу з новими завданнями; суб'єкти навчання чи виробничники є невід'ємною частиною установки, механізму; забезпечення практичної спрямованості, перетворення знань у безпосередню виробничу силу. Звідси випливає проблема створення нового освітнього середовища - STEM-орієнтованого освітнього середовища, яке передбачає поєднання природничих наук, технологій, технічної дослідницької творчості та математики. Отже, невід'ємною частиною зазначеного середовища $є$ ЦТ.

Наказом Міністерства освіти і науки України від 29 квітня 2020 року № 574 затверджено «Типовий перелік навчально-методичного забезпечення, засобів навчання та обладнання для навчальних кабінетів і STEM-лабораторій» (https://zakon.rada. gov.ua/laws/show/z0410-20\#Text), одним із компонентів якого визначено 3D-ручки разом із витратними матеріалами на навчальний рік. Хоча цей засіб навчання задекларований для використання в початковій школі, на нашу думку, його використання варто розширити на весь освітній процес у закладі загальної середньої освіти як засіб активізації пізнавальної активності учнів, формування їхнього абстрактного мислення, інформаційно-цифрової та STEM-компетентності.

Метою статті $\epsilon$ розроблення методики навчання фізики з використанням цифрових засобів як чинник забезпечення формування в учнів STEM-компетентності.

Виклад основного матеріалу дослідження. Проблемою вдосконалення методики навчання фізики у школі займалися багато вчених, серед них такі: П.С. Атаманчук, В.Ф. Заболотний, О. I. Іваницький, Б.Г. Кремінський, М.Т. Мартинюк, А.І. Павленко, М.І. Садовий, В.Д. Шарко та ін. Реалізації засад цифровізації в освітньому процесі шкільного курсу фізики та впровадженню STEM-технологій присвятили свої дослідження Ю.П. Бендес, А.М. Кух, О.С. Мартинюк, Н.А. Мислицька, I.О. Мороз, М.І. Садовий, І.А. Сліпухіна, Д.В. Соменко, М.В. Хомутенко, І.С. Чернецький та ін. Незважаючи на значну кількість досліджень, присвячених окресленій проблемі, стрімкі темпи цифровізації та розвитку науково-технічного прогресу вимагають систематичного оновлення та вдосконалення методики навчання фізики в закладах загальної середньої освіти.

Нами здійснено аналіз досліджень науковців, нормативних документів Міністерства освіти i науки України останніх п'яти років [8], який визначив ряд системних проблем щодо реального стану реалізації освітньої політики в Україні із впровадження засад цифровізації в освітньому процесі. Зокрема:

- за результатами зовнішнього незалежного оцінювання спостерігається зниження рівня предметної компетентності 3 фізики випускників закладів загальної середньої освіти та погли-

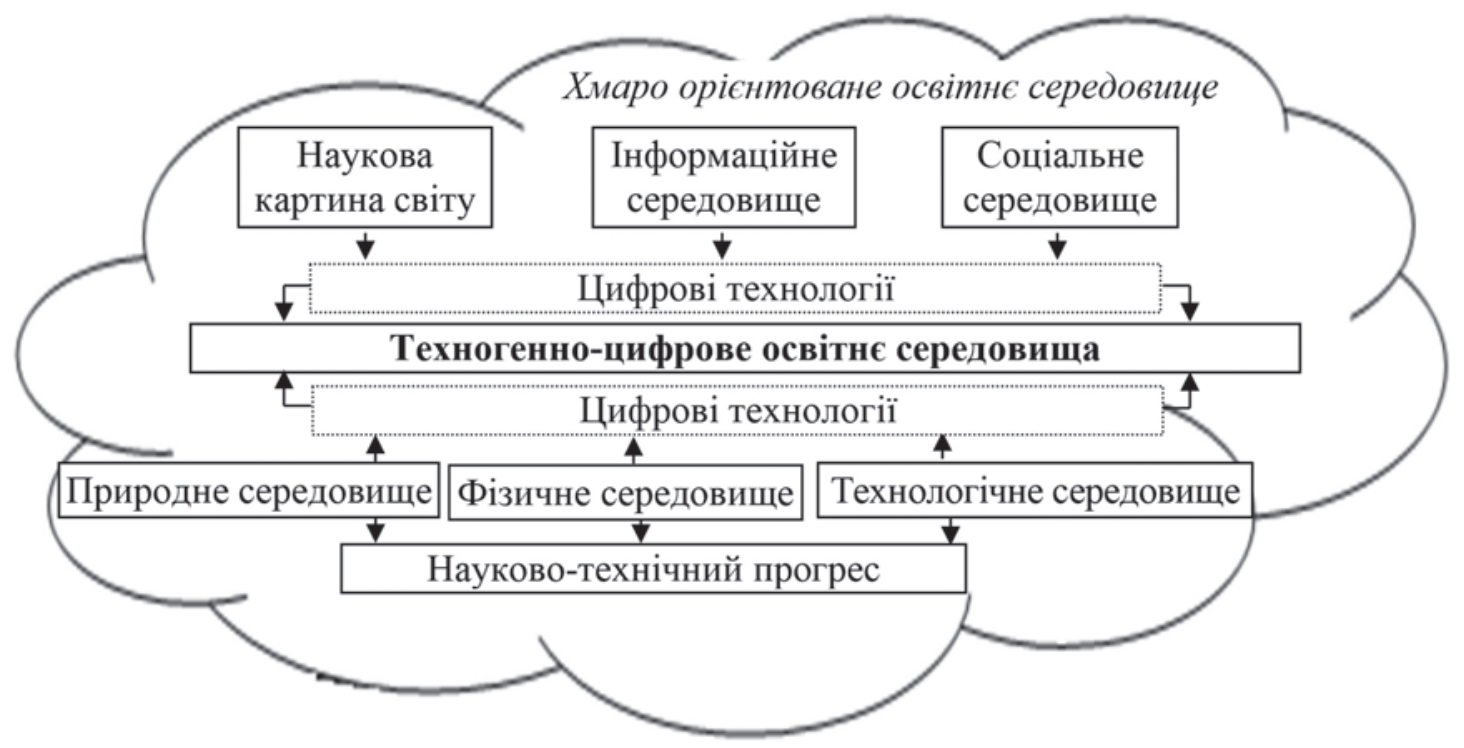

Рис. 1. Модель техногенно-цифрового освітнього середовища [8] 
блення розриву між рівнями засвоєння фізико-математичних знань і вимогами суспільства до рівня STEM-компетентності сучасної особистості;

- поглиблення розриву між традиційними підходами до формування якості знань здобувачів освіти й об'єктивними потребами науки, техніки, виробництва та інших галузей людської діяльності в компетентних фахівцях, здатних до розв'язання нестандартних проблем в умовах становлення техногенно-інформаційного суспільства;

- неспроможність традиційних технологій навчання задовольнити потребу інтенсифікації процесу здобуття освіти засобами цифрових технологій;

- невідповідність рівня розвитку науки та сучасної наукової картини світу рівню розвитку випускників закладів загальної середньої освіти;

- зниження попиту серед абітурієнтів на спеціальності природничо-математичного спрямування.

Окреслені проблеми передбачають потребу створення та забезпечення систематичного функціонування STEM-освітнього середовища, основою якого є STEM-технології (рис. 2) навчання природничо-математичних дисциплін. Як один iз шляхів реалізації STEM-технологій ми вбачаємо навчання засобів тримірного зображення натурних і модельних явищ, процесів, що має інноваційно-орієнтоване спрямування. Методичні особливості реалізації зазначеного підходу передбачають: 1) ознайомлення здобувачів освіти 3 основами сучасного 3D-конструювання та моделювання; 2) формування вмінь використовувати 3D-пристрої, найпростішим 3 яких є 3D-ручка; 3) розвиток STEM-компетентності, здатності до організації власної проектної діяльності та передбачення іiї результатів; 4) активізацію пізнавальної активності здобувачів освіти, розвиток їхніх інтелектуальних і творчих здібностей, акцентування уваги на перспективності професій, пов'язаних із природничо-математичною галуззю знань.

Із метою забезпечення формування STEM-компетентності учнів основної школи під час навчання фізики нами визначено особливості запровадження використання 3D-ручки в освітньому процесі (табл. 1).

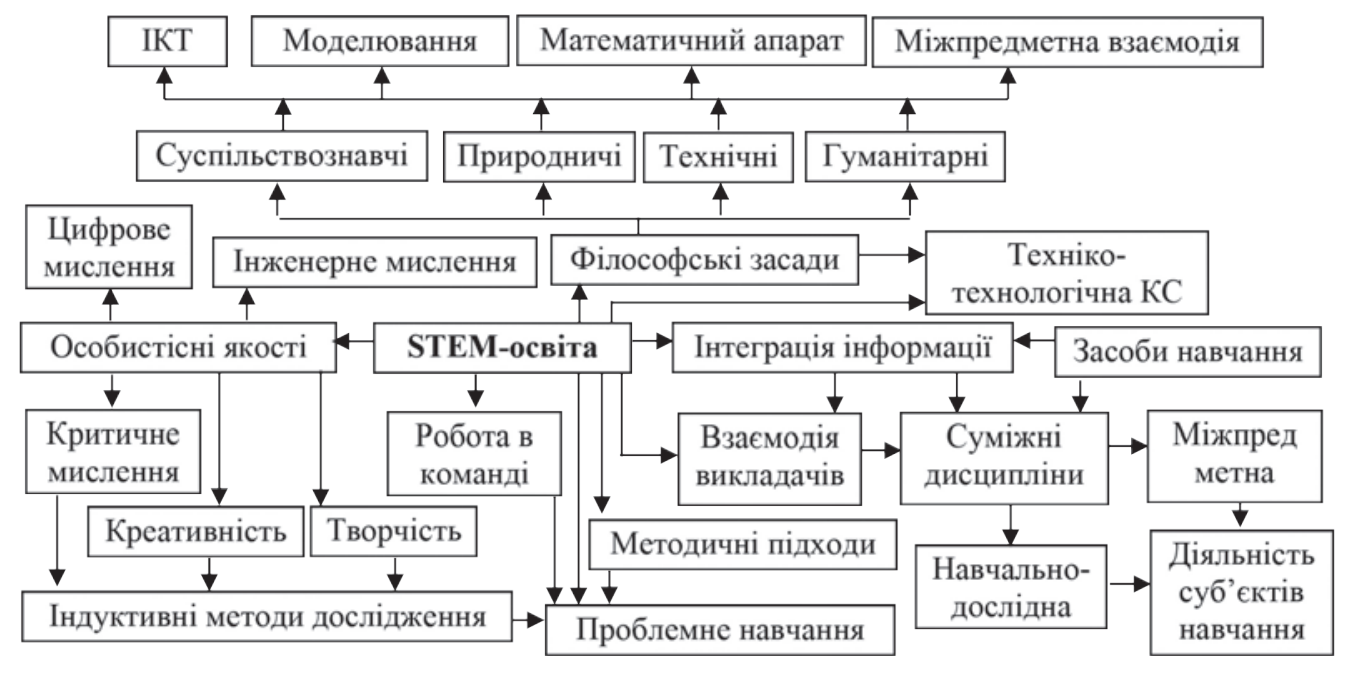

Рис. 2. Структурно-логічна схема моделі STEM-технологій [7]
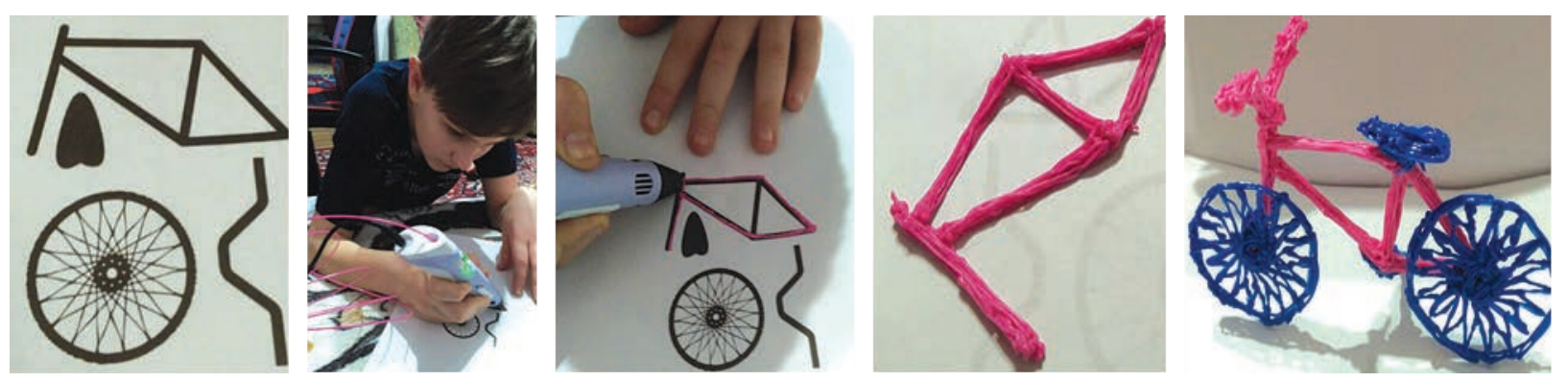

Рис. 3. Етапи створення велосипеду за допомогою 3D-ручки (на фото Левченко Антон Романович - учень філії «Богданівська загальноосвітня школа» опорного навчального закладу «Богданівська загальноосвітня школа I-III ступенів імені І.Г. Ткаченка Суботцівської сільської ради Кропивницького району Кіровоградської області») 

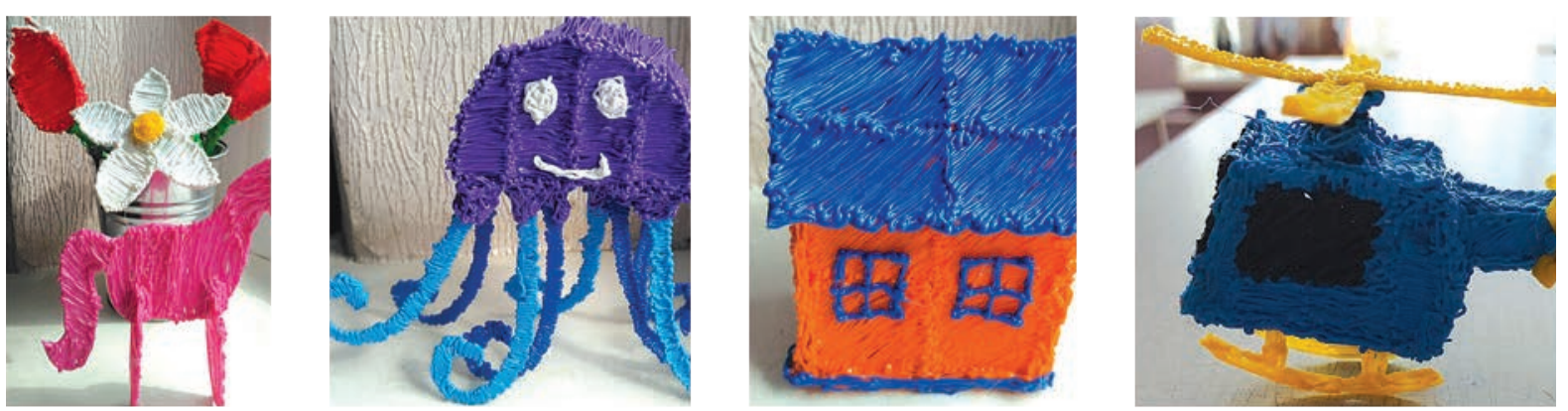

Рис. 4. Об’скти створені за допомогою 3D-ручки (автор Левченко Антон Романович)

Таблиця 1

Особливості запровадження використання 3D-ручки в освітньому процесі з фізики основної школи

\begin{tabular}{|c|c|}
\hline $\begin{array}{l}\text { Зміст навчального } \\
\text { матеріалу }\end{array}$ & $\begin{array}{l}\text { Змістові компоненти, під час навчання яких } \\
\text { ми пропонусмо використовувати 3D-ручки }\end{array}$ \\
\hline \multicolumn{2}{|r|}{7 клас } \\
\hline $\begin{array}{l}\text { ВСТУП. Фізика як } \\
\text { навчальний предмет у школі }\end{array}$ & $\begin{array}{l}\text { Виготовлення моделей окремих фізичних приладів, наприклад, штативів, } \\
\text { динамометрів тощо. }\end{array}$ \\
\hline $\begin{array}{l}\text { Розділ 1. Фізика як } \\
\text { природнича наука. } \\
\text { Пізнання природи }\end{array}$ & $\begin{array}{l}\text { Виготовлення моделей молекул різних речовин. } \\
\text { Створення різноманітних фізичних об’єктів (на вибір учнів) та обговорення } \\
\text { фізичних величин та одиниць їх вимірювання, які необхідні для опису розмірів } \\
\text { та поведінки обраних учнями об’єктів. }\end{array}$ \\
\hline Розділ 2. Механічний рух & $\begin{array}{l}\text { Створення різноманітних фізичних об’єктів (на вибір учнів) та обговорення фізичних } \\
\text { величин та одиниць їх вимірювання, які необхідні для опису поведінки обраних } \\
\text { учнями об’єктів. Тобто створивши, наприклад, за допомогою 3D-ручки велосипед } \\
\text { (рис. 3) або гелікоптер (рис. 4), учні можуть обговорити поняття руху, видів руху, часу, } \\
\text { системи координат, відносності руху, швидкості, траєкторії руху і т.д. }\end{array}$ \\
\hline $\begin{array}{l}\text { Розділ 3. Взаємодія тіл. } \\
\text { Сила }\end{array}$ & $\begin{array}{l}\text { Виготовлення за допомогою 3D-ручки тіл різної форми і дослідження за } \\
\text { допомогою створених моделей різних видів сил (наприклад, сили тертя кочення, } \\
\text { ковзання і т.д.). } \\
\text { Дослідження з однією з виготовлених моделей дії сили пружності, сили тяжіння. } \\
\text { Вивчення понять деформації та ваги тіла. } \\
\text { Дослідження дії виштовхувальної сили в рідинах на обраний (виготовлений } \\
\text { за допомогою 3D-ручки) об’єкт. }\end{array}$ \\
\hline $\begin{array}{l}\text { Розділ 4. Механічна робота } \\
\text { та енергія }\end{array}$ & $\begin{array}{l}\text { Виготовлення за допомогою 3D-ручки простих механізмів та обговорення } \\
\text { фізичних законів їхнього функціонування. }\end{array}$ \\
\hline \multicolumn{2}{|r|}{8 клас } \\
\hline Розділ 1. Теплові явища & $\begin{array}{l}\text { Обговорення понять температури, температури плавлення, зокрема, плавлення } \\
\text { пластику у 3D-ручці. } \\
\text { Виготовлення моделей твердих тіл. }\end{array}$ \\
\hline $\begin{array}{l}\text { Розділ 2. Електричні явища. } \\
\text { Електричний струм }\end{array}$ & Обговорення будови і принципу дії 3D-ручки. \\
\hline \multicolumn{2}{|r|}{9 клас } \\
\hline Розділ 1. Магнітні явища & $\begin{array}{l}\text { Створення моделі досліду Ерстеда, магнітного поля Землі, гучномовця, } \\
\text { постійного магніту із силовими лініями і т.д. }\end{array}$ \\
\hline Розділ 2. Світлові явища & $\begin{array}{l}\text { Моделювання за допомогою 3D-ручки реалізації законів прямолінійного } \\
\text { поширення світла, законів відбивання та заломлення. } \\
\text { Виготовлення моделей різних видів лінз та найпростіших оптичних приладів. }\end{array}$ \\
\hline $\begin{array}{l}\text { Розділ 3. Механічні та } \\
\text { електромагнітні хвилі }\end{array}$ & $\begin{array}{l}\text { Виготовлення моделі електромагнітної хвилі та обговорення особливостей } \\
\text { „ї поширення у середовищі. }\end{array}$ \\
\hline $\begin{array}{l}\text { Розділ 4. Фізика атома та } \\
\text { атомного ядра. Фізичні } \\
\text { основи атомної енергетики }\end{array}$ & $\begin{array}{l}\text { Виготовлення моделі атома за допомогою 3D-ручки, обговорення історичних } \\
\text { етапів становлення уявлень про будову атома та сучасні погляди вчених } \\
\text { на структуру атома. }\end{array}$ \\
\hline $\begin{array}{l}\text { Розділ 5. Рух і взаємодія. } \\
\text { Закони збереження }\end{array}$ & $\begin{array}{l}\text { Дослідження руху тіла під дією кількох сил. } \\
\text { Створення моделі ракети. }\end{array}$ \\
\hline Фізика й екологія & $\begin{array}{l}\text { Обговорення проблем вторинного використання пластику, } \\
\text { вплив пластику на екологію та живі організми. }\end{array}$ \\
\hline
\end{tabular}


Запропоновані елементи впровадження 3D-ручки (табл. 1) як засобу навчання в освітній процес із фізики забезпечують підвищення пізнавальної активності учнів, сприяють реалізацію принципу політехнічної направленості навчання фізики. Формування таким чином STEM-компетентності вчить учнів самостійно мислити, отримувати та застосовувати знання, планувати свою діяльність, приймати рішення, презентувати результати діяльності, ефективно працювати в STEM-освітньому середовищі, сприяє розвитку в них комунікативної компетентності.
Висновки і перспективи подалыших розробок у цьому напрямку. Застосування сучасних цифрових засобів навчання в закладах загальної середньої освіти $є$ визначальним формуючим чинником освітнього середовища, що сприяє вирішенню ряду навчальних задач та формуванню як предметної компетентності $з$ фізики, так і STEM-компетентності учнів, сприяє підвищенню їхньої пізнавальної активності. Стрімкі темпи цифровізації всіх галузей суспільства вимагають систематичного удосконалення освітнього процесу з фізики та визначають перспективи подальших розробок у цьому напрямку.

\section{ЛІТЕРАТУРА}

1. Бойко П.С., Бойко М.С. Використання 3D-ручки на уроках фізики та математики. Міжпредметні зв'язки природничо-математичних дисциплін в освітньому процесі: матер. Всеукр. наук.-практ. Інтернет-конф., 10-12 березня 2021 р. Луцьк, 2021. С. 85-89.

2. Концепція розвитку природничо-математичної освіти (STEM-освіти) / розп. КМУ від 05.08.2020 р. № 960-p URL : https://zakon.rada.gov.ua/laws /show/960-2020-\%D1\%80\#Tехt (дата звернення: 22.07.2021).

3. Садовий M.I. Моделювання хмарних послуг як практичне втілення STEM-освіти. STEM-освіта - проблеми та перспективи: зб. матер. III Міжнар. наук.-практ. семінару, 24-25 жовтня 2018 р., Кропивницький, 2018. С. 71-73.

4. Садовий M.І. Цифрові технології як засіб підвищення мотивації учнів в освітньому процесі 3 природничих дисциплін. Реалї та перспективи природничо-математичної підготовки у закладах освіти: матер. наук.-практ. конф., 12-13 вересня 2019 р. Херсон, 2019. С. 50-53.

5. Сліпухіна I.A., Чернецький I.C. Використання цифрового вимірювального комплексу в STEM орієнтованому освітньому середовищі. Ukrainian Journal of Educational Studies and Information Technology. 2017. Vol. 5(1). P. 279-289. URL : https://uesit.org.ua/index.php/ itse/article/view/171/156 (дата звернення: 22.07.2021).

6. Соменко Д.В. Використання апаратно-обчислювальної платформи Arduino в навчальному процесі 3 фізики : посіб. для студ. фіз.-мат. фак-тів пед. унів-тів. Кіровоград : ПП «ЦОП «Авангард», 2013.88 с.

7. Трифонова O.M. STEM середовище навчання фізико-технічних дисциплін. Зб. наук. пр. Кам'янець-Подільського наи. ун-ту імені Івана Огієнка. Серія педагогічна. Кам'янець-Подільський, 2018. Вип. 24: STEM-інтеграція як важлива передумова управління результативністю та якістю фізичної освіти. С. 37-41.

8. Трифонова О.М. Методична система розвитку інформаційно-цифрової компетентності майбутніх фахівців комп'ютерних технологій у навчанні фізики і технічних дисциплін : дис. ... д-ра пед. наук : 13.00.02, 13.00.04 / ЦДПУ ім. В. Винниченка. Кропивницький, 2020. 595 с.

9. Фізика 7-9 класи: навчальна програма для загальноосвітніх навчальних закладів / затв. Наказом МОНУ від 07.06.2017 № 804. URL : https://mon.gov.ua/ua/osvita/zagalna-serednya-osvita/navchalniprogrami/navchalni-programi-5-9-klas (дата звернення: 16.07.2021).

\section{REFERENCES}

1. Boyko P.S., Boyko M.S. (2021) Vykorystannya 3D-ruchky na urokakh fizyky ta matematyky [Using a 3D-pen in physics and math lessons]. Mizhpredmetni $z v^{\prime \prime y a z k y ~ p r y r o d n y c h o-m a t e m a t y c h n y k h ~ d y s t s y p l i n ~} v$ osvitn'omu protsesi: mater. Vseukr. nauk.-prakt. Internet-konf., 10-12 bereznya 2021. Luts'k. S. 85-89.

2. Kontseptsiya rozvytku pryrodnycho-matematychnoyi osvity (STEM-osvity) (2020) [The concept of development of natural and mathematical education (STEM-education)] skhvaleno rozporyadzh. KMU vid 05.08.2020. № 960-r URL: https://zakon.rada.gov.ua/laws/show/960-2020-\%D1\%80\#Text (data zvernennya: 22.07.2021).

3. Sadovyi M.I. (2018) Modelyuvannya khmarnykh posluh yak praktychne vtilennya STEM-osvity [Modeling of cloud services as a practical implementation of STEM-education]. STEM-osvita-problemy ta perspektyvy: zb. mater. III Mizhnar. nauk.-prakt. seminaru, 24-25 zhovtnya 2018 r., Kropyvnyts'kyy. S. 71-73.

4. Sadovyi M.I. (2019) Tsyfrovi tekhnolohiyi yak zasib pidvyshchennya motyvatsiyi uchniv v osvitn'omu protsesi z pryrodnychykh dystsyplin [Realities and prospects of natural and mathematical training in 
educational institutions]. Realiyi ta perspektyvy pryrodnycho-matematychnoyi pidhotovky u zakladakh osvity: mater. nauk.-prakt. konf., 12-13 veresnya 2019 r. Kherson. S. 50-53.

5. Slipukhina I.A., Chernets'kyy I.S. (2017) Vykorystannya tsyfrovoho vymiryuval'noho kompleksu v STEM oriyentovanomu osvitn'omu seredovyshchi [Use of digital measuring complex in STEM oriented educational environment]. Ukrainian Journal of Educational Studies and Information Technology. Vol. 5 (1). S. 279-289. URL: https://uesit.org.ua/index.php/itse/article/view/171/156 (data zvernennya: 22.07.2021)

6. Somenko D.V. (2013) Vykorystannya aparatno-obchyslyuval'noyi platformy Arduino v navchal'nomu protsesi z fizyky [The use of hardware and computing platform Arduino in the educational process in physics]: posib. dlya stud. fiz.-mat. fak-tiv ped. univ-tiv. Kirovohrad : PP «TSOP «Avanhard». $88 \mathrm{~s}$.

7. Tryfonova O.M. (2018) STEM seredovyshche navchannya fizyko-tekhnichnykh dystsyplin [STEM learning environment for physical and technical disciplines]. Zb. nauk. pr. Kam"yanets'-Podil's'koho nats. un-tu imeni Ivana Ohiyenka. Seriya pedahohichna. Kam"yanets'-Podil's'kyy, Vyp. 24: STEM-intehratsiya yak vazhlyva peredumova upravlinnya rezul'tatyvnistyu ta yakistyu fizychnoyi osvity. S. 37-41.

8. Tryfonova O.M. (2020) Metodychna systema rozvytku informatsiyno-tsyfrovoyi kompetentnosti maybutnikh fakhivtsiv komp"yuternykh tekhnolohiy u navchanni fizyky i tekhnichnykh dystsyplin [Methodical system of development of information-digital competence of future specialists of computer technologies in teaching physics and technical disciplines]: dys. ... d-ra ped. nauk : 13.00.02, 13.00.04 / TSDPU im. V.Vynnychenka. Kropyvnyts'kyy, 2020. 595 s.

9. Fizyka 7-9 klasy: navchal'na prohrama dlya zahal'noosvitnikh navchal'nykh zakladiv (2017) [Physics 7-9 grades: curriculum for secondary schools] / zatv. Nakazom MONU vid 07.06.2017 № 804. URL: https://mon.gov.ua/ua/osvita/zagalna-serednya-osvita/navchalni-programi/navchalni-programi-5-9-klas (data zvernennya: 16.07.2021). 